\title{
Correction to: Current status of development of methylation biomarkers for in vitro diagnostic IVD applications
}

Olga Taryma-Leśniak, Katarzyna Ewa Sokolowska and Tomasz Kazimierz Wojdacz ${ }^{*}$

\section{Correction to: Clinical Epigenetics (2020) 12:100 \\ https://doi.org/10.1186/s13148-020-00886-6}

After publication of the original article [1], the authors notified that only dr. Tomasz Kazimierz Wojdacz should be marked as corresponding author.

The original article has been updated.

Published online: 14 July 2020

\section{Reference}

1. Taryma-Leśniak, et al. Clin Epigenetics. 2020;12:100 https://doi.org/10.1186/ s13148-020-00886-6.

The original article can be found online at https://doi.org/10.1186/s13148020-00886-6.

* Correspondence: tomasz.wojdacz@pum.edu.p

Independent Clinical Epigenetics Laboratory, Pomeranian Medical University, Unii Lubelskiej 1, 71-252 Szczecin, Poland

(c) The Author(s). 2020 Open Access This article is licensed under a Creative Commons Attribution 4.0 International License, which permits use, sharing, adaptation, distribution and reproduction in any medium or format, as long as you give appropriate credit to the original author(s) and the source, provide a link to the Creative Commons licence, and indicate if changes were made. The images or other third party material in this article are included in the article's Creative Commons licence, unless indicated otherwise in a credit line to the material. If material is not included in the article's Creative Commons licence and your intended use is not permitted by statutory regulation or exceeds the permitted use, you will need to obtain permission directly from the copyright holder. To view a copy of this licence, visit http://creativecommons.org/licenses/by/4.0/. The Creative Commons Public Domain Dedication waiver (http://creativecommons.org/publicdomain/zero/1.0/) applies to the data made available in this article, unless otherwise stated in a credit line to the data. 